\title{
Effect of Model-Based Training by Nurses on the Promotion of Sleep Patterns among Students in the Middle School
}

\section{Ilköğretim Ikinci Basamak Öğrencilerinin Uyku Düzeninin lyileștirilmesinde Modele Temellendirilmiș Hemșirelik Eğitiminin Etkisi}

\author{
๑ Aysel Topan, ๑ Duygu Gözen* \\ Zonguldak Bülent Ecevit University Faculty of Health Sciences, Department of Nursing, Zonguldak, Turkey \\ *Istanbul University-Cerrahpașa Florence Nightingale Faculty of Nursing, Department of Pediatric Nursing, Istanbul, Turkey
}

\begin{abstract}
Objective: This study evaluates the effect of health promotion modelbased nursing interventions on the development of sleep patterns in children of middle school.

Materials and Methods: The study included students who were in middle school in the City Center of Zonguldak during the 2011-2012 academic year $(n=5287)$. The number of students in the sample group was determined as 358 based on the formula used in situations where the frequency is unknown. The study was performed as a pretest, posttest, and experiment with a control group. The study was conducted on 84 students who had the lowest sleep pattern scores and constituted $25 \%$ of the sample group.

Results: The intervention group participated in a Sleep Pattern Promotion Program that was intended to promote sleep pattern behavior. A statistically significant difference was observed between the students in the intervention and control groups related to the total mean scores on the third measurement after 3 months of program application ( $\mathrm{p}=0.002)$.

Results: Nursing intervention based on Pender's Health Promotion Model was deduced to be effective in promoting sleep patterns.

Keywords: Adolescence, sleep pattern, health promotion model, nursing intervention
\end{abstract}

Öz

Amaç: Araştırma ilköğretim okullarının ikinci basamağında öğrenim gören çocukların uyku düzeninin iyileştirilmesinde Sağlığı Geliştirme Modeli'ne temellendirilen hemşirelik girişimlerinin uyku düzeni davranışı üzerindeki etkisini değerlendirmek amacıyla planlanmıștır.

Gereç ve Yöntem: Araştırmanın evrenini 2011-2012 eğitim öğretim yılında Zonguldak II Merkezi'nde, ilköğretim okullarında öğrenim gören $(n=5287)$ öğrenciler oluşturmuştur. Örneklem grubu öğrenci sayısı evrenin bilindiği, sıklığın bilinmediği durumlarda kullanılan formül doğrultusunda 358 olarak belirlenmiş̧ir. Araştırma ön test, son test, kontrol gruplu deneysel uygulanmış ve uyku düzeni ölçeği uygulanan örneklem grubundan puanı en az olan \%25'i oluşturan 84 öğrenci ile gerçekleştirilmiştir.

Bulgular: Deney grubuna, uyku düzeni davranışını geliştirmeye yönelik Uyku Düzeni Geliştirme Programı uygulanmışır. Bu program uyguladıktan 3 ay sonraki üçüncü ölçümde deney ve kontrol gruplarındaki öğrencilerin toplam puan ortalamaları arasında istatistiksel olarak ileri düzeyde anlamlı farklılık olduğu saptanmıştır $(p<0,002)$.

Sonuç: Pender'in Sağlığı Geliştirme Modeli'ne temellendirilerek uygulanan hemşirelik girişiminin uyku düzeninin geliştirilmesinde etkili olduğu belirlenmiştir.

Anahtar Kelimeler: Adolesan, uyku düzeni, sağlığı geliştirme modeli, hemşirelik girişimi

\section{Introduction}

Sleep is an essential necessity for living since it is a vital and physiological process for the maintenance of healthy functioning of the brain cells and body system (1). It is very crucial for the health and life quality in all ages and is also principle element for reinforcement of physical growth and academic performance $(2,3)$. In the studies of recent years, it was indicated that sleeping has a positive effect on functions associated with learning, memory and mental behaviour (4-6). In some scientific studies, it was reported that measurable significant reductions were present in the attention, concentration, learning and memory skills of children whose sleep durations showed a decrease of one hour for one week. 
There are also some studies showing that reading, writing and problem solving abilities were disrupted in children who have an insufficient sleep (7).

Early adolescence (10-15 years) is a period which they move from primary to secondary education and experience rapid and profound changes in their lives. Rapid physiological and cognitive changes are observed and health-related behaviors are started to be gained in this developmental phase. In addition, adolescents take responsibility for their health attitudes and become independent (8). According to data from the National Sleep Foundation dated 2006, 21\% of children in secondary education were reported to be inadequate (less than 8 hours) on nights when they went to school the next day, and only $35 \%$ slept on the ideal time (9-10 hours). This is the motivation why our study focused on the secondary school students.

In health promotion studies, training of the students and their parents about importance of sleeping by school nurses is very important in terms of ensuring that they take responsibility for healthy behaviour and increasing awareness about importance of this subject by group discussions $(9,10)$. The studies done in line with this model have a highly important role in the constitution of health promotion programs. In this context, studies based on the health promotion model provide guidance in terms of the prevention and improvement of individuals' health, the constitution of positive health behaviors, and the identification of the factors affecting health promotion (11).

In the identification of an individual's health behavior and the factors of this behavior, theories and models that were developed for this subject are used. These theories and models complement each other; they provide a more meaningful, understandable, and solution-focused approach to the condition (9).

In our study, it was decied to use Pender's Health Promotion Model, which is the most suitable nursing intervention model, in order to realize changing the behaviour and health promotion to establish a "Sleep pattern promotion program" in the training program given to the students.

\section{Materials and Methods}

Study design: This study is preliminary test-post test intervention study with control group that was carried out to determine the effect of nursing interventions on sleep pattern behaviour in improvement of sleep patterns of children who were educated in the second level of primary schools (11-14 years).

Setting and sample: The study was performed in official primary schools located in City Center of Zonguldak. The study universe was composed of students $(n=5287)$ who were having their education in the $6^{\text {th }}, 7^{\text {th }}$ and $8^{\text {th }}$ classes of 35 official primary schools located in the City Center of Zonguldak during 2011-2012 academic year.

The formula which is used for conditions where the universe is known, however the frequency is unknown, was used for selection of sample group. Sample size was determined as 358 with a $90 \%$ confidence interval, 50\% prevalance and 5\% margin of error. In order to obtain the number of students in the sample group, two public primary schools with the most heterogenous structure were chosen for the study by the cluster sampling method. "Personal Information and Sleep Pattern Information form" and "Sleep Pattern scale" were performed to students who were educated in $6^{\text {th }}, 7^{\text {th }}$ and $8^{\text {th }}$ classes of those schools. A ranking, starting from the ones with the worst sleep pattern towards the better, was done based on the results obtained from sleep pattern scale for the purpose of the study. As a result of this ranking, the students constituting the lower $25 \%$ segment were enrolled into the intervention and control groups by random assignment starting from the ones with lowest scores in the scale. Accordingly, a total of 84 students as 42 in the intervention group and 42 in the control were participated in the study (Figure 1).

Ethical consideration: Before the data collection period, permissions were taken from relevant institutions for implementation of the study and to avoid ethical problems. The ethical approval was received from the Zonguldak Karaelmas University Faculty of Medicine, Ethical Committee of Human Research (approval number: 2010/07, date: 05.08.2010).

Measurement instruments: Followings are the measurement instruments in this research.

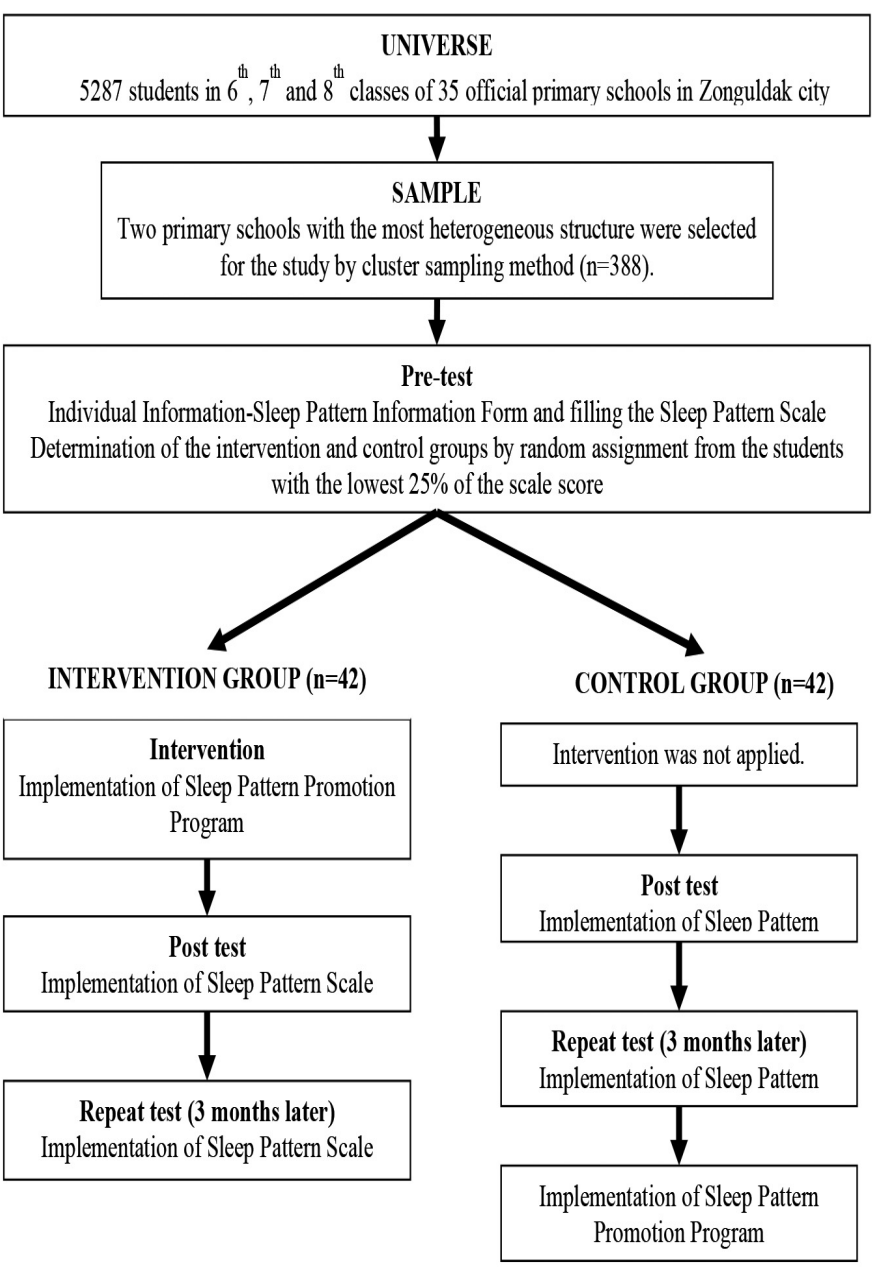

Figure 1. Research pettern 
- Personal Information and Sleep Pattern Information form: This form was prepared by the researchers after the review of relevant literature and edited with the expert opinions. Sociodemographic characteristics of students and their parents and sleep patterns of these students were involved in this form.

- Sleep Pattern scale: Sleep Pattern scale is a scale consisting of a total of 50 questions that were determined after a validity-reliability study by Ozgur (12) to be used to determine sleep pattern. When scale scoring was assessed, the minimum score that would be obtained from all items of the scale was evaluated as 50 and the maximum score as 150 , with one point from each item being minimum and three points being maximum. In the scale, 50 points show that the individual never cares about sleep pattern; the score range of 51-100 shows that the individual sometimes cares about sleeping pattern and the score range of 101150 means that the individual always cares about the sleeping pattern. Sleep Pattern scale was performed for total of 430 students and the reliability coefficient was reported to be 0.85 during the validity-reliability study of scale.

Data collection and procedure: Preliminary study was carried out with a group of 30 people who were educated in second level of different public school and who were not included in the study. During the implementation phase of the study;

Pre-intervention (Preliminary test): Personal Information and Sleep Pattern Information form and Sleep Pattern scale were performed to both intervention and control groups between October 10-15, 2011.

During the intervention phase; "Sleep pattern promotion program" was applied to the students in intervention group included in the study. This program was developed by the researcher in accordance with Pender's Health Promotion Model. The duration of program was three weeks and it consisted of total of five sessions as two sessions per week. The duration of each session was determined as 20 minutes.

Training sessions of Sleep pattern promotion program; Session 1: Determination of the purpose of the study, Session 2: Concept of Health and Health Promotion, Session 3: Importance of Sleep and Sleep Pattern, Session 4: Good Quality Sleep, Session 5: Sleep Diary Program.

The Sleep Diary was developed by the National Sleep Fourndation to help children for their learning sleep patterns, self-control of their sleep patterns, and information to help them learn about sleep patterns. This diary has been translated into Turkish by the authors under the permission taken (appendix 1) and used to improve the student's behavior in the sleep diary program. Within the scope of the training, the sleep diary was given to the students and they were asked to fill the sleep pattern activities on this diary for 4 weeks. New sleep diaries were given to students in the future.

Post-intervention (Post test): Sleep Pattern scale was performed to both intervention and control groups between December 1-5, 2011.
Three months after the intervention (Repeat test): Sleep Pattern scale was again performed to both intervention and control groups between Mart 01-05, 2012.

\section{Statistical Analysis}

Statistical analysis was performed by using SPSS 18.0 program. The conformity of numerical variables to normal distribution was examined by Shapiro-Wilk test (0.012). In descriptive statistics, numerical data were expressed as mean \pm standard deviation values (minimum-maximum) and categorical variables were expressed as number and percentage. Intergroup differences in terms of categorical variables were assessed by chi-square test. In terms of numerical variables, Student's t-test was used when parametric test assumptions were met and Mann-Whitney $\mathrm{U}$ test was used if they were not met. The comparison of three groups for numerical variables was done by Kruskal-Wallis analysis since parametric test assumptions were not met. Changes over time were analysed by One-Way variance analysis for repeated measures for repeated measures that showed normal distribution; and by Friedman test for repeated measures without normal distribution. The results were evaluated within $95 \%$ confidence interval and $p<0.05$ was considered as statistically significant.

\section{Results}

When students included in the study were evaluated in terms of age, it was found that mean age of intervention group was $12.26 \pm 0.86$, and it was $12.14 \pm 0.89$ in control group. When the students in the intervention and control groups were compared in terms of age, both groups showed statistically homogenous distribution ( $p>0.05)$.

When the students were evaluated in terms of gender, it was observed that $45.2 \%$ of students included in intervention group $(n=19)$ and $40.5 \%$ of control group $(n=17)$ were girls; and $54.8 \%$ of intervention group $(n=23)$ and $59.5 \%$ of the control group $(n=25)$ were boys. During statistical analysis, it was seen that there was no statistically significant difference in terms of gender between both groups ( $p>0.05)$.

It was observed that bedtimes, waking hours and total sleep durations during the week/weekend were statistically similar as shown by Table 1 ( $p>0.05)$.

As shown by Table 2, no statistically significant difference was found between intervention and control groups in terms of dinner time, activity before bedtime, availability of drinking milk, bedtime and form of waking in the morning ( $>0.05$ ).

Any statistically significant difference was not found between the students in intervention and control groups in terms of sleeping room, bed type, presence of noise around the room, room temperature, presence of television in the room, presence of computer at home, permission status of decision-making for bedtime and turning the light off before bedtime according to the Table 3 ( $p>0.05)$.

It was determined that there was no statistically significant difference between mean total scores in first, second and third measurements of students in intervention and control groups based on gender $(p>0.05)$ (Table 4$)$. 


\begin{tabular}{|c|c|c|c|c|c|c|c|}
\hline \multirow[b]{2}{*}{ Features } & \multicolumn{2}{|c|}{ Experimental group $(n=42)$} & \multicolumn{2}{|c|}{ Control group $(n=42)$} & \multicolumn{2}{|c|}{ Total $(n=84)$} & \multirow{2}{*}{$\begin{array}{l}\text { Test values } \\
x^{2} ; p \\
\end{array}$} \\
\hline & $\mathbf{n}$ & $\%$ & $\mathbf{n}$ & $\%$ & $\mathbf{n}$ & $\%$ & \\
\hline \multicolumn{8}{|l|}{ Bedtime } \\
\hline \multicolumn{8}{|c|}{ Bedtimes during the week } \\
\hline $\begin{array}{l}20-22 \\
23-01\end{array}$ & $\begin{array}{l}20 \\
22\end{array}$ & \begin{tabular}{|l|}
7.6 \\
52.4
\end{tabular} & $\begin{array}{l}21 \\
21\end{array}$ & \begin{tabular}{|l|}
50.0 \\
50.0
\end{tabular} & $\begin{array}{l}41 \\
43\end{array}$ & \begin{tabular}{|l|}
48.8 \\
51.2
\end{tabular} & $0.048 ; 0.827$ \\
\hline \multicolumn{8}{|c|}{ Bedtimes during weekend } \\
\hline $\begin{array}{l}20-22 \\
23-01 \\
02-04\end{array}$ & \begin{tabular}{|l|}
4 \\
34 \\
4 \\
\end{tabular} & \begin{tabular}{|l|}
9.5 \\
81.0 \\
9.5 \\
\end{tabular} & \begin{tabular}{|l|}
7 \\
31 \\
4 \\
\end{tabular} & \begin{tabular}{|l|}
16.7 \\
73.8 \\
9.5 \\
\end{tabular} & \begin{tabular}{|l|}
11 \\
65 \\
8 \\
\end{tabular} & \begin{tabular}{|l|}
13.1 \\
77.4 \\
9.5 \\
\end{tabular} & $0.957 ; 0.617$ \\
\hline \multicolumn{8}{|c|}{ Waking hour } \\
\hline \multicolumn{8}{|c|}{ Waking-hour during the week } \\
\hline $\begin{array}{l}05-07 \\
08-10\end{array}$ & $\begin{array}{l}38 \\
4\end{array}$ & $\begin{array}{l}90.5 \\
9.5\end{array}$ & $\begin{array}{l}33 \\
9\end{array}$ & $\begin{array}{l}78.6 \\
21.4 \\
\end{array}$ & $\begin{array}{l}71 \\
13 \\
\end{array}$ & $\begin{array}{l}84.5 \\
15.5 \\
\end{array}$ & $2.275 ; 0.131$ \\
\hline \multicolumn{8}{|c|}{ Waking-hour during weekend } \\
\hline $\begin{array}{l}07-09 \\
10-12 \\
13-15 \\
\end{array}$ & \begin{tabular}{|l|}
14 \\
25 \\
3 \\
\end{tabular} & \begin{tabular}{|l|}
33.3 \\
59.5 \\
7.2 \\
\end{tabular} & \begin{tabular}{|l|}
18 \\
21 \\
3 \\
\end{tabular} & \begin{tabular}{|l|}
42.9 \\
50.0 \\
7.1 \\
\end{tabular} & \begin{tabular}{|l|}
32 \\
46 \\
6 \\
\end{tabular} & \begin{tabular}{|l|}
38.1 \\
54.8 \\
7.1 \\
\end{tabular} & $0.848 ; 0.654$ \\
\hline \multicolumn{8}{|c|}{ Total sleep duration } \\
\hline \multicolumn{8}{|c|}{ Total sleep duration during the week } \\
\hline $\begin{array}{l}05-07 \\
08-10 \\
11-13 \\
\end{array}$ & \begin{tabular}{|l|}
10 \\
30 \\
2 \\
\end{tabular} & \begin{tabular}{|l|}
23.8 \\
71.4 \\
4.8 \\
\end{tabular} & \begin{tabular}{|l|}
7 \\
31 \\
4 \\
\end{tabular} & \begin{tabular}{|l|}
16.7 \\
73.8 \\
9.5 \\
\end{tabular} & \begin{tabular}{|l|}
17 \\
61 \\
6 \\
\end{tabular} & \begin{tabular}{|l|}
20.2 \\
72.6 \\
7.1 \\
\end{tabular} & $1.212 ; 0.541$ \\
\hline \multicolumn{8}{|c|}{ Total sleep duration during weekend } \\
\hline $\begin{array}{l}05-07 \\
08-10 \\
11-13 \\
\end{array}$ & \begin{tabular}{|l|}
4 \\
20 \\
18 \\
\end{tabular} & \begin{tabular}{|l|}
9.5 \\
47.6 \\
42.9 \\
\end{tabular} & \begin{tabular}{|l|}
3 \\
28 \\
11 \\
\end{tabular} & \begin{tabular}{|l|}
7.1 \\
66.7 \\
26.2 \\
\end{tabular} & \begin{tabular}{|l|}
7 \\
48 \\
29 \\
\end{tabular} & \begin{tabular}{|l|}
8.3 \\
57.2 \\
34.5 \\
\end{tabular} & $3.166 ; 0.203$ \\
\hline Total & 42 & 100.0 & 42 & 100.0 & 84 & 100.0 & \\
\hline
\end{tabular}

\begin{tabular}{|c|c|c|c|c|c|c|c|}
\hline \multirow[t]{2}{*}{ Features } & \multicolumn{2}{|c|}{ Experimental group $(n=42)$} & \multicolumn{2}{|c|}{ Control group $(n=42)$} & \multicolumn{2}{|c|}{ Total $(\mathrm{n}=\mathbf{8 4})$} & \multirow{2}{*}{\begin{tabular}{|l|} 
Test values \\
$\mathrm{x}^{2} ; \mathrm{p}$
\end{tabular}} \\
\hline & $n$ & $\%$ & $\mathbf{n}$ & $\%$ & $\mathbf{n}$ & $\%$ & \\
\hline 18 & 5 & 11.9 & 7 & 16.7 & 12 & 14.2 & $3.784 ; 0.176$ \\
\hline 19 & 23 & 54.8 & 21 & 50.0 & 44 & 52.4 & \\
\hline 20 & 11 & 26.2 & 13 & 30.9 & 24 & 28.6 & \\
\hline Elektronic device usage (computer, TV) & 29 & 69.0 & 23 & 54.8 & 52 & 61.9 & $1.817 ; 0.178$ \\
\hline Reading/writing activity & 13 & 31.0 & 19 & 45.2 & 32 & 38.1 & \\
\hline \multicolumn{8}{|c|}{ Availability of drinking milk before bedtime } \\
\hline Yes & 6 & 14.2 & 10 & 23.8 & 16 & 19.0 & $1.249 ; 0.535$ \\
\hline No & 13 & 31.0 & 12 & 28.6 & 25 & 29.8 & \\
\hline At the same time & 11 & 26.2 & 18 & 42.9 & 29 & 34.5 & \\
\hline \multicolumn{8}{|l|}{ Form of waking in the morning } \\
\hline Hearing morning alarm & 11 & 26.2 & 14 & 33.3 & 25 & 29.8 & $4.609 ; 0.465$ \\
\hline Awakening by a family member & 18 & 42.9 & 19 & 45.2 & 37 & 44.0 & \\
\hline Her/himself & 10 & 23.8 & 8 & 19.0 & 18 & 21.4 & \\
\hline Other & 3 & 7.1 & 1 & 2.4 & 4 & 4.8 & \\
\hline Total & 42 & 100.0 & 42 & 100.0 & 84 & 100.0 & \\
\hline
\end{tabular}


Topan and Gözen.

Model-Based Nursing Training for Promotion of Students' Sleep Pattern

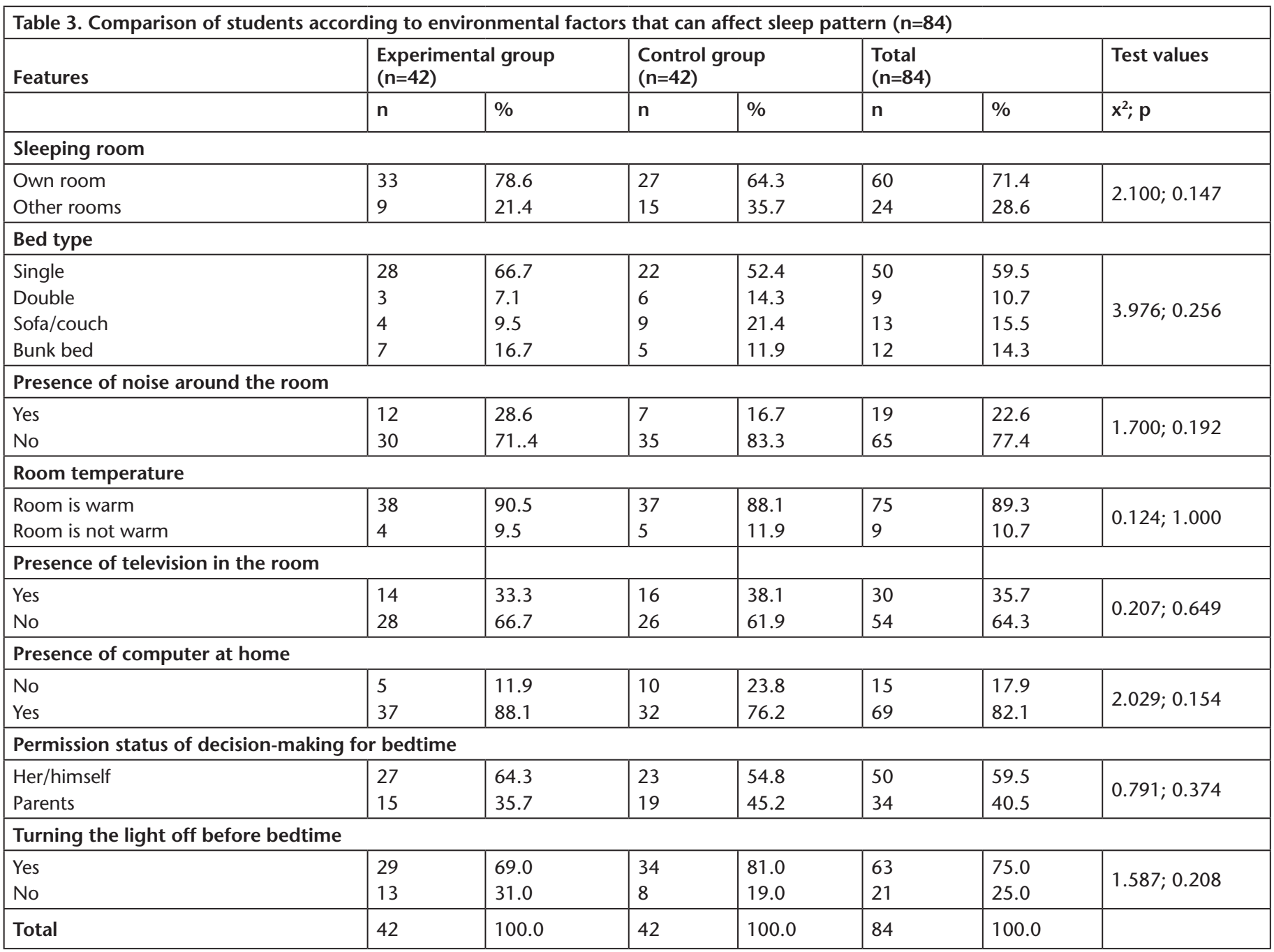

\begin{tabular}{|c|c|c|c|c|c|c|c|}
\hline Group & Feature $(n)$ & $\begin{array}{l}\text { First measurement } \\
\bar{\chi} \pm S D\end{array}$ & $\begin{array}{l}\mathrm{t} \\
p\end{array}$ & $\begin{array}{l}\text { Second } \\
\text { measurement } \\
\bar{\chi} \pm \text { SD }\end{array}$ & $\begin{array}{l}\mathrm{t} \\
\mathrm{p}\end{array}$ & $\begin{array}{l}\text { Third } \\
\text { measurement } \\
\bar{\chi} \pm \text { SD }\end{array}$ & $\begin{array}{l}t \\
p\end{array}$ \\
\hline \multirow[b]{2}{*}{ Experimental Group } & Girls (19) & $106.8 \pm 6.6$ & \multirow{2}{*}{$\begin{array}{l}-1.940 \\
0.052\end{array}$} & $106.4 \pm 6.5$ & \multirow{2}{*}{$\begin{array}{l}-1.737 \\
0.082\end{array}$} & $111.8 \pm 12.2$ & \multirow{2}{*}{$\begin{array}{r}-0.683 \\
0.494\end{array}$} \\
\hline & Boys (23) & $102.2 \pm 8.3$ & & $102.0 \pm 8.1$ & & $108.5 \pm 7.1$ & \\
\hline \multirow{3}{*}{ Control Group } & Girls (17) & $104.7 \pm 3.7$ & \multirow{3}{*}{$\begin{array}{l}-0.167 \\
0.867\end{array}$} & $104.5 \pm 4.0$ & \multirow{3}{*}{$\begin{array}{l}-0.026 \\
0.979\end{array}$} & $104.5 \pm 3.6$ & \multirow{3}{*}{$\begin{array}{r}-0.180 \\
0.857\end{array}$} \\
\hline & Boys (25) & $103.8 \pm 8.9$ & & $103.4 \pm 8.5$ & & $103.5 \pm 8.5$ & \\
\hline & Total (42) & $104.1 \pm 7.2$ & & $103.8 \pm 7.0$ & & $103.9 \pm 6.9$ & \\
\hline
\end{tabular}

It was observed that no statistically significant difference was found between total mean scores of students in intervention and control groups in the first, second and third measurements according to dinner time $(p>0.05)$. A statistical significant difference was found between mean total scores of the students in intervention group at the third measurement performed after training in terms of activity before bedtime $(p=0.03)$; however there was not statistically significant difference between mean total scores of students in the control group at third measurement ( $p>0.05)$ (Table 5).

While no significant difference was found between the mean total scores of intervention and control groups before the implementation of sleep pattern promotion program (pre-test) and at second measurement just after implementation of sleep 
pattern promotion program (post-test), it was determined that there was statistically significant difference between mean total scores of both groups at the third measurement 3 months after implementation of program $(p=0.002)$ (Table 6).

\section{Discussion}

This study was performed based on the hypothesis that a sleep pattern promotion program, which is based on Pender's Health
Promotion model, that is intended for the promotion in the sleep pattern. When mean age of students in intervention and control groups included in the study were examined, it was determined that adolescents were between 10-14 years, in other words, they were in early adolescence period, total sleep duration of $72.6 \%$ of students during week and $57.2 \%$ of them during weekend were between mean of 8-10 hours and their mean score in sleep pattern scale was 104.2 17.5 (70-129). In

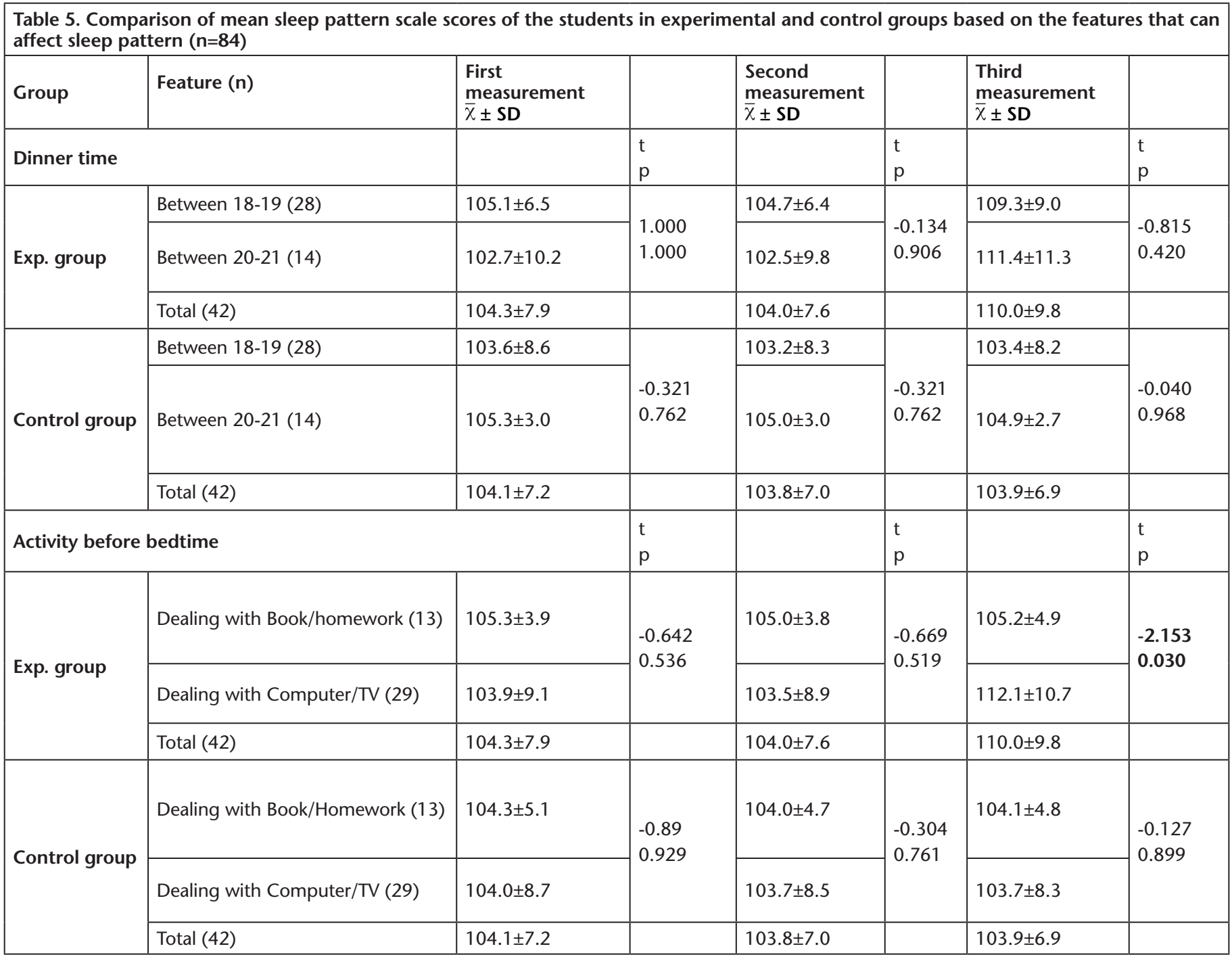

\begin{tabular}{|l|l|l|l|l|}
\hline \multicolumn{4}{|l|}{ Table 6. Comparison of mean scores of the students in Sleep Pattern scale (n=84) } \\
\hline $\begin{array}{l}\text { Sleep Pattern scale group } \\
\text { scores }\end{array}$ & $\begin{array}{l}\text { Pre test (1) } \\
\bar{\chi} \pm \text { SS (min-max) }\end{array}$ & $\begin{array}{l}\text { Post test (2) } \\
\bar{\chi} \pm \text { SS (min-max) }\end{array}$ & $\begin{array}{l}\text { Repeat test (3) } \\
\bar{\chi} \pm \text { SS (min-max) }\end{array}$ & F, p \\
\hline $\begin{array}{l}\text { Experimental Group } \\
\text { Control Group }\end{array}$ & $\begin{array}{l}104.3 \pm 7.9(70-129) \\
104.1 \pm 7.2(70-119)\end{array}$ & $\begin{array}{l}104.0 \pm 7.6(71-128) \\
103.8 \pm 7.0(70-116)\end{array}$ & $\begin{array}{l}110.0 \pm 9.8(91-136) \\
103.9 \pm 6.9(70-116)\end{array}$ & $\begin{array}{l}19.1^{* *}, 0.000 \\
9.3^{* *}, 0.009\end{array}$ \\
\hline $\begin{array}{l}\text { Total } \\
\text { t, p }\end{array}$ & $104.2 \pm 7.5(70-129)$ & $103.9 \pm 7.3(70-128)$ & $106.9 \pm 8.9(70-136)$ \\
\hline $\begin{array}{l}\text { *: Mann-Whitney U test was used since the scores were not showing normal distribution, **: Friedman test was used since the scores were not showing normal } \\
\text { distribution }\end{array}$ & $-0.027^{*}, 0.979$ & $-0.03^{*}, 0.975$ & $\mathbf{0 . 0 0 2}$ \\
\hline
\end{tabular}


addition, it was seen that there was no significant difference between groups in terms of sleep durations and sleep pattern scale scores. As reported by (13), children between 6-10 years were sleeping for $9.62 \pm 1.08$ hours and children between 11-12 years were sleeping for $9.42 \pm 1.23$ hours, (14) have found in their study that children between 12-13 years were sleeping for 10, 9.45 and 8.45 hours, respectively. In a study by (15), it was reported that the students were sleeping for a mean of $9.08 \pm 1.72$ hours during the week and for $9.44 \pm 2.45$ hours during the weekend. In our country, mean sleep duration of students between 7-10 years old in Kırıkkale was found to be $10.1 \pm 1.1$ hours as reported by (16) and it was reported to be $8.86 \pm 1.10$ hours among $6^{\text {th }}, 7^{\text {th }}$ and $8^{\text {th }}$ class children in Kayseri by (17). When the results of our study were compared with the literature, it was seen that total daily sleep duration varied between 8-10 hours and results were similar to data obtained from the studies in same age group (13-15,17). Accordingly, it was suggested that total sleep duration of the adolescents was sufficient, and they showed similar characteristics with children living in different regions in terms of sleep duration.

Sleep is factor that positively affects the success of school age children. It was reported that daily activities of children were negatively affected, there was an increase in somnolence, deterioration in mood and rate of showing risky behaviours, and children encountered some difficulties in learning as result of insufficient sleep $(18,19)$. In study by $(20)$, it was shown that school children did not feel well about themselves when their sleep duration was decreased. Therefore, it was emphasized that school children and their families should be aware of the importance of sufficient sleep and the consequences of sleep deprivation. Out of students in intervention and control groups included in the study, $50 \%$ went to sleep after the time that they need to sleep, $51.2 \%$ during week and $77.4 \%$ during the weekend went to sleep between 11.00 pm-01.00, waking time of $84.5 \%$ was between $05.00-07.00$ during the week and waking time of $54.8 \%$ was between 10.00-12.00 during the weekend. Investigating the effects of delaying bedtime on school children resulted that $17 \%$ of children were sleeping after 23.00, they were waking in a bad mood, falling asleep at frequent intervals throughout the day, were late to school more often and started studying lessons at home one hour later when compared with the students sleeping before 23.00 (15). When our study was compared with the literature, it was seen that half of students included in the study went to sleep later than recommended bedtime and this was found to be higher than results obtained by (15). It was thought that this situation was due to the differences in these countries, and more attention on order of life in Japan was considered to affect the result. Also in this study, one of most important reasons of borderline mean scores in sleep patterns of students in intervention and control groups were considered to be due to irregularities in bedtime hours.

For a good quality sleep, environmental factors also have to be regulated. It was reported that environmental factors such as temperature, light, sound and electromagnetic field affect sleep. It was also shown that electromagnetic field created by devices such as mobile phone, television, computer, etc. has negative effects on biological systems and humans such as sleeping disorders, headache and myalgia. Furthermore, light and sound propagated by these types of devices were known to complicate falling asleep (21). In the study performed by (22), it was reported that insomnia was much more seen among the children sleeping in a noisy and bright place. When the conditions of the rooms where the students in the intervention and control groups included in this study were investigated, it was determined that television was present in $35.7 \%$, noise was present in $22.6 \%$, room temperature was not sufficient in $10.7 \%$ and $25 \%$ were sleeping under light. As reported by (23), it was shown that there was television in the sleeping room in $26 \%$, and problems about falling asleep and general sleeping disorders were seen much more among school-age children. In the study by (24), it was reported that the television existed in the sleeping room in $18.5 \%$ of children and computer in $18.3 \%$. In the study performed by Karacal (25) in Konya city, the frequency of presence of electronic device in the sleeping room was found to be 56.6\%; and in a study by Bulduk, either computer or television existed in the sleeping room in $60 \%$ of children between the age of 11-16 years (16). When our results were compared with the existing studies, percentage of the presence of television in the sleeping room was found to be lower than the studies by (16) and (25) while it was found to be higher than the results in the studies by (24) and (19). This difference was considered due to the variation between the countries and the cultures.

In the performed studies, it was shown that irregular bedtime habits were present among the children who watched television or played computer during the last half an hour before going to sleep, and they fell asleep throughout the day due to shortening of the duration of sleep $(24,26,27)$. Among activities performed by the students in intervention and control groups during last half an hour before sleeping, usage of electronic device (television, computer, etc.) was in first place $(61.9 \%)$ and reading/writing activity was in the second place $(38.1 \%)$. The presence of television or computer in the rooms of children negatively affect their sleep habits. It was supposed that this situation was due to the parents' lack of information regarding sleep pattern of children and their insufficient attention for their sleep patterns.

It was observed that there was no statistically significant difference between the mean scores obtained from first and second measurements in the sleep pattern scale in terms of activities of children in intervention group before bedtime; however, there was statistically significant difference between the students using electronic device (television, computer, etc.) and dealing with a reading/writing activity before bedtime at the third measurement $(p<0.05)$. It was reported by $(23)$ performed in England that $25 \%$ of children were watching television before going to sleep. In addition, it was observed that in the studies by (28) on the children in Belgium and by (29) in India, listening to music was in the first place among the behaviours before bedtime in $42 \%$ of children, (28) have reported that children were secondly reading books before 
going to sleep (50\%). It was seen that preferably usage of electronic device before sleeping was slightly higher among the students included in the study compared to other studies $(23,28,29)$. Mean scores in sleep pattern of the students using electronic device (television, computer, etc.) and dealing with reading/writing activity before bedtime in intervention group were estimated significantly higher $(p<0.05)$; and this situation forced us to think that the quality of sleep pattern of the students who were dealing with electronic device before bedtime was increased since they were positively affected by the training.

It was also observed that out of the students in the intervention and control groups included in the study, 44\% were awakened by their parents, $29.8 \%$ were awakened by alarm clock and $21.4 \%$ by themselves. Reviewing the existing studies, Ozgur (12) has reported that $5.6 \%$ of students were awakened by their family members, $29.5 \%$ were by alarm clock and $17.4 \%$ by themselves. Comparing with the findings of Ozgur (12), it was seen that awakening forms of students in the morning were similar. Self-awakening in the morning is accepted as indication of a good quality and sufficient sleep (30). The necessity for person or alarm clock to be awakened for majority of students made us think that they were not having good quality sleep and the duration of sleep was insufficient.

Total mean sleep pattern scores of the intervention and control groups were assessed three times as before "Sleep pattern promotion program" (first measurement), after the program (second measurement) and 3 months after the end of the program (third measurement). In these measurements, mean scores in Sleep Pattern scale among the students in intervention group were found to be statistically higher than control group. While there was no statistically significant difference between the total mean Sleep Pattern scores of the students in the intervention and control groups at the first and second measurements, a statistically significant difference was found between total mean sleep pattern scores at the third measurement which was performed 3 months after the program $(p<0.05)$. The hypothesis that "mean scores of the students in sleep pattern scale in intervention group who were performed Sleep Pattern promotion program would be higher than the control group" was confirmed with this result (31). Have investigated the effect of sleep hygiene training program that addressed sleep-wake cycle, sleep quality and insomnia, on 58 Brazilian adolescent students in their study; and they reported that there was a reduction in the sleep irregularities and delay in falling asleep, the durations of sleeping-waking were improved. However, there was no difference in sleep quality and daytime sleepiness after training program lasting for one week (32). Have carried out a research to study the sleep quality of the officers working in an information technology company in Japan during the daytime, and they performed a sleep hygiene training program for the participants. They provided a significant promotion in their sleep quality at the end of the training program lasting for 3 weeks. In the study by (31), it was indicated that there was a promotion in the sleep pattern of students with the sleep hygiene training program; and consistent with this result, promotion was also observed in sleep pattern of students after the sleep pattern promotion program. In the study by (32), a promotion was also provided in the sleep quality of participants with sleep hygiene training program performed for officers. According to this study, getting similar results despite performing on different age groups compel us to think that there are some findings that support the efficient role of sleep training in the regulation of sleep patterns. Occurrence of the promotion in sleep patterns among the children, who were performed sleep pattern promotion program, over long period of three months is remarkable finding. This finding shows efficiency of the training and it confirms that behavioural changes were positively improved. It was thought that "sleep diary" provides self-control of sleep pattern behaviours by students was effective in behavioural change. All students in the intervention group have recorded their sleep patterns on daily and weekly basis in diary; and thus, auto-control was achieved. This situation has ensured the success in behavioural changes of students.

The nursing training activities increased the children's sensitivity to their sleep pattern behaviour. With these sleep pattern training activities, the children became aware of the negative effects of unfavourable or insufficient sleep pattern behaviours on good quality sleep. At the same time, they gained some behaviours that would promote sleep pattern. One of the reasons that this study was based on Pender's Health Promotion model was that Pender has indicated that the practice of changing behaviour might be improved by helping individuals to understand their feelings regarding the behaviour. The improvement in the behaviours that contribute to positive sleep patterns in the intervention group included in this study leads to a conclusion that the nursing model created for the promotion of sleep pattern behaviour is effective.

\section{Conclusion}

This study was based on Pender's Health Promotion model, and a nursing training model was created for the improvement of sleep patterns. It was concluded that the health promotion model that was created for the improvement of sleep patterns was considered to be a feasible guideline in promoting the sleep pattern behaviours of adolescents.

\section{Ethics}

Ethics Committee Approval: The ethical approval was received from the Zonguldak Karaelmas University Faculty of Medicine, Ethical Committee of Human Research (approval number: 2010/07, date: 05.08.2010).

Informed Consent: Before the data collection period, permissions were taken from relevant institutions for implementation of the study and to avoid ethical problems.

Peer-review: Internally peer-reviewed.

\section{Authorship Contributions}

Concept: A.T., D.G., Design: A.T., D.G., Data Collection or Processing: A.T., D.G., Analysis or Interpretation: A.T., D.G., Literature Search: A.T., D.G., Writing: A.T., D.G. 
Conflict of Interest: No conflict of interest was declared by the authors.

Financial Disclosure: The authors declared that this study received no financial support.

\section{References}

1. Ertugrul A, Rezaki M. Uykunun nörobiyolojisi ve bellek üzerine etkileri. Turk Psikiyatri Dergisi 2004;15:300-8.

2. Ozturk MC, Dicle A, Sari H, Yildirim BM. Determining health situation of school children. Milli Eğitim Dergisi 2004;163:156-67.

3. Fadıloglu $\mathrm{Cl}$, Yesim $\mathrm{Y}$, Yasemin $\mathrm{K}$. Sleep quality among nursing home residents. Turkish Journal of Geriatrics 2006;9:165-9.

4. Sadeh A, Gruber R, Raviv A. The effect of sleep restriction and extention on school-age children: what a difference an hour makes. Child Dev 2003;74:444-55.

5. Ward TM, Rankin S, Lee KA. Caring for children with sleep problems. J Pediatr Nurs 2007;22:283-96.

6. Ulus $S$, Senel F. Sleep and dream. TÜBITAK Science and Technique 2005; 1:161-71.

7. Taylor DJ, Vatthauer KE, Bramoweth AD, Ruggero C, Roane B. The role of sleep in predicting college academic performance: is it a unique predictor? Behav Sleep Med 2013;11:159-72.

8. Carskadon MA, Acebo C. Regulation of sleepiness in adolescents: update, insights, and speculation. Sleep 2002;25:606-14.

9. Chen MY, Wang EK, Jeng YJ. Adequate sleep among adolescents is positively associated with health status and health-related behaviors. BMC Public Health 2006;6:59.

10. Shin YH, Kang SJ. Health behaviors and related demographic factors among Korean adolescents. Asian Nurs Res (Korean Soc Nurs Sci) 2014;8:150-7.

11. Pender NJ, Murdaugh CL, Parsons MA, Ann M. Health promotion in nursing practice. 4th ed. New Jersey, Pearson Prentice Hall, 2006.

12. Ozgur K. The investigation of sleep patterns of 5th, 6th, 7th, and 8th. grade primary school students. Bursa, Uludağ University, 2009.

13. Liu X, Ma Y, Wang Y, Jiang Q, Rao X, Lu X, Teng H. Brief Report: An epidemiologic survey of the prevalence of sleep disorders among children 2 to 12 years old in Beijing, China. Pediatrics 2005;115(1 Suppl):266-8.

14. Giannotti F, Cortesi F, Sebastiani T, Vagnoni C. Sleeping habits in Italian children and adolescents. Sleep and Biological Rhythms 2005;3:15-21.

15. Yoshimatsu S, Hayashi M. Bedtime and lifestyle in primary school children. Sleep and Biological Rhythms 2004;2:153-5.

16. Bulduk R. Sleeping characteristics of children aged 0-16 years living in Kirikkale city [MS]. Ankara, Gazi University, 2005.
17. Unalan D, Ozturk A, Ismailogullari S, Akgul N, Aksu M. The effect of sleep duration and quality on academical success of the elementary school children in Kayseri Turkey. J Pak Med Assoc 2013;63:576-80.

18. Fallone G, Owens JA, Deane J. Sleepiness in children and adolescents: Clinical implications. Sleep Med Rev 2002;6:287-306.

19. Owens JA. The practice of pediatric sleep medicine: results of a community survey. Pediatrics 2001;108:e51.

20. Kelman BB. The sleep needs of adolescents. J Sch Nurs 1999;15:14-9.

21. Seze RD, Fabro-Peray P, Miro L. GSM radiocellular telephones do not disturb the secretion of antepituitary hormones in humans. Bioelectromagnetics 1998;19:271-8.

22. Kahn A, Van de Merckt C, Rebuffat E, Mozin MJ, Sottiaux M, Blum D, Hennart P. Sleep problems in healty preadolescents. Pediatrics 1984:542-6.

23. Owens J, Maxim R, McGuinn M, Nobile C, Msall M, Alario A. Television-viewing habits and sleep disturbance in scholl children. Pediatrics 1999;104:27.

24. Li SH, Jin XM, Wu SH, Jiang F, Yan $C H$, Shen XM. The impact of media use on sleep patterns and sleep disorders among school-aged children in China. Sleep 2007;30:361-7.

25. Karacal S. Sleep disorders prevalencea of children aged 0-17 years living in Konya. Konya: Selçuk Üniversitesi; 2010.

26. Alexandru G, Michikazu S, Shimako H, Xiaoli C, Hitomi K, Takashi Y, Robert WW, Sadanobu K. Epidemiological aspects of self-reported sleep onset latency in Japanese junior high school children. J Sleep Res 2006; 15:266-75.

27. Bahammam A, Alfairs E, Shaikh S, Saeed AB. Prevalence of sleep problems and habits in a sample of Saudi primary school children. Ann Saudi Med 2006;26:7-13.

28. Eggermont S, Bulck JV. Nodding off or switching off? The use of popular media as a sleep aid in secondary-school children. J Pediatr Child Health 2006;42:428-33.

29. Bharti B, Malhi P, Kashyap S. Patterns and problems of sleep in school going children. Indian Pediatr. 2006;43:35-8.

30. Kaynak D. Sleep and its disorder in adolescents. In: Ercan O, Alikaşifoğlu M, Ercan G (eds). Proceedings of Symposium Series of Adolescent Health of Medicine Continuing Medical Education Meetings; Istanbul University Cerrahpaşa Faculty of Medicine. Kaya Basım, İstanbul, 2005;135-46.

31. Sousa IC, Araújo JF, Azevedo CVM. The effect of a sleep hygiene education program on the sleep-wake cycle of Brazilian adolescent students. Sleep and Biological Rhythms 2007;5:251-8.

32. Nishinoue N, Takano T, Kaku A, Eto R, Kato N, Ono Y, Tanaka K. Effects of sleep hygiene education and behavioral therapy on sleep quality of white-collar workers: a randomized controlled trial. Ind Health 2012;50:123-31. 